Sains Malaysiana 50(6)(2021): 1639-1650

http://doi.org/10.17576/jsm-2021-5006-11

\title{
New Hybrid Strains via Intraspecific Protoplast Fusion of the Entomopathogenic Fungi Lecanicillium spp.
}

(Strain Hibrid Baharu melalui Pelakuran Protoplas Intraspesies oleh Kulat Entomopatogen Lecanicillium spp.)

\author{
Liang LiU, Chunlai LiU, Lili Yan, Fanyang, Shuang Wang, Xifeng Jiang \& XinMin Li*
}

\section{ABSTRACT}

The entomopathogenic fungal genus Lecanicillium Gams and Zare (formerly classified as the species Verticillium lecanii) includes species that are highly pathogenic to many insect genera. In this study, we identified six Lecanicillium spp. isolated strains (designated as V1-V6) belonging to L. lecanii (V1, V3 and V5) and L. attenuatum (V2, V4 and V6). In addition, these strains were used to obtain new strains via protoplast fusion, and nit mutants were used for protoplast selection. Genetic recombination of the hybrid strains was determined using the random amplified polymorphic DNA (RAPD) technique. We obtained nine stable fusant strains from 176 new hybrid strains, which were termed $V_{12}-10, V_{14}-3$, $V_{16}-4, V_{23}-6, V_{25}-8, V_{34}-14, V_{36}-5, V_{45}-16$ and $V_{56}-7$. Morphological characteristics varied between the hybrid and parental strains. Genomic DNA analysis of the fusants also showed genetic recombination. The median lethal concentration $\left(L C_{50}\right)$ for the fusants were lower than that for parental strains, and the median survival time $\left(L T_{50}\right)$ for the fusants were reduced compared with that for parental strains. Thus, these results showed that we produced new, more virulent hybrid Lecanicillium spp. strains as biological control agents via intraspecific protoplast fusion.

Keywords: Hybrid strains; L. attenuatum; L. lecannii; pathogenicity; protoplast fusion

\section{ABSTRAK}

Genus kulat entomopatogen Lecanicillium Gams dan Zare (dahulunya dikelaskan sebagai spesies Verticillium lecanii) merangkumi spesies yang sangat patogen ke atas banyak genera serangga. Dalam kajian ini, kami mengenal pasti enam strain pencilan Lecanicillium spp. (dinamakan sebagai V1-V6) yang merupakan L. lecanii (V1, V3 dan V5) dan L. attenuatum (V2, V4 dan V6). Selain itu, strain ini digunakan untuk memperoleh strain baharu melalui pelakuran protoplas dan mutan nit digunakan untuk pemilihan protoplas. Gabungan semula genetik strain hibrid ditentukan menggunakan teknik DNA polimorfik rawak (RAPD). Sembilan strain fusant stabil diperoleh daripada 176 strain hibrid baharu yang disebut sebagai $V_{12}-10, V_{14}-3, V_{16}-4, V_{23}-6, V_{25}-8, V_{34}-14, V_{36}-5, V_{45}-16$ dan $V_{56}{ }^{-7}$. Ciri morfologi didapati berbeza antara strain hibrid dan induk. Analisis DNA genom fusant juga menunjukkan berlakunya gabungan semula genetik. Median kepekatan maut $\left(L C_{50}\right)$ untuk fusant adalah lebih rendah daripada strain induk dan median masa kebolehhidupan (LT $\left.{ }_{50}\right)$ untuk fusants berkurang berbanding strain induk. Oleh itu, keputusan ini menunjukkan bahawa kami menghasilkan strain hibrid Lecanicillium spp. baru yang lebih virulen serta mampu bertindak sebagai agen kawalan biologi melalui pelakuran protoplas intraspesies.

Kata kunci: Kepatogenan ; L. lecannii; L. attenuatum; pelakuran protoplas; strain hibrid

\section{INTRODUCTION}

Entomopathogenic fungi are effective natural enemies of insect pests, thus, useful for biocontrol applications as environmentally friendly pest control agents or alternatives to chemical insecticides (Almeida et al. 2019; Nyasani et al. 2015). Lecanicillium spp. are important entomopathogenic fungi for controlling tiny sucking insects, particularly aphids, thrips, whiteflies, and nematodes in agricultural greenhouses (Reddy \& Sahotra 2018; Wraight et al. 2017). Based on morphological observations and molecular analyses, the new genus Lecanicillium includes five species (L. longisporum, L. lecanii, L. attenuatum, $L$. 
muscarium, and L. nodulosum), which were all formerly classified as V. lecanii (Zimm.) (Gams \& Zare 2001; Zare et al. 2000). Many strains with valuable potential insecticidal activity against specific insect pests have been isolated and developed as commercial biopesticides (Ruiu 2018; Solter et al. 2017). However, there are many bottlenecks limiting the application of these fungi. Unlike chemical pesticides, fungal pathogens have been hampered by their lack of efficacy and the requirement for high amounts of inocula (Fang et al. 2014; Vega et al. 2009). Thus, isolating or optimising strains to obtain high-performance fungal pathogens for use in pest insect control has been a focus of extensive research efforts.

Virulence can be improved through genetic engineering (Peng \& Xia 2015; Xie et al. 2015) and protoplast fusion methods (Singh et al. 2015; Strom \& Bushley 2016). Genetic modification increases the killing speed of L. lecanii. In the most recent study to improve fungal virulence, exogenous pathogenic genes were transferred into L. lecanii via an optimised polyethylene glycol-mediated protoplast transformation system (Zhang et al. 2016). Meanwhile, protoplast fusion has become a critical tool for strain improvement to induce genetic recombination and produce new hybrid strains of fungi (Leland \& Gore 2017; Patil et al. 2015). Additionally, protoplast fusion has great potential for genetic analysis because it eliminates the barriers to genetic exchange imposed by conventional mating systems. Protoplast fusion has been widely used to improve fungal strains for alcohol fermentation, thus enhancing the yield of cellulose to ethanol and to produce new citric acid strains of Aspergillus niger (Strom \& Bushley 2016).

Moreover, this technique has previously been used for genetic manipulation via the interspecific or selffusion of protoplasts to modify industrially important fungi (Dahlmann et al. 2015). Protoplast fusion is also an extremely valuable tool in the development of fungal pathogen strains for commercialisation as biocontrol agents (Hassan 2014). Nitrate non-utilising (nit) mutants that are unable to grow on media containing chlorate can be used for visual selection of positive hybrids in several fungal species through complementation testing via protoplast fusion (Parthiban et al. 2018).

The major advantages of using nit mutants are that spontaneous mutations can be easily carried out to produce mutants and efficiently selected by their resistance to chlorate, and they are classified phenotypically on minimal medium with different nitrogen sources.
Furthermore, nit mutants can be easily recovered without mutagenic treatment. Mycotal and Vertalec are commercialised strains that are used to control insects, and the protoplast fusion method has already been used to develop new hybrid strains from these original strains. Aiuchi et al. (2008) described 174 new isolates, and some of these hybrid strains exhibited enhanced biocontrol efficacy.

Currently, molecular techniques such as random amplified polymorphic DNA (RAPD), PCR restriction fragment length polymorphism (PCR-RFLP), intersimple sequence repeat PCR (ISSR-PCR) and denaturing gradient gel electrophoresis (DGGE) analyses are used to identify individual strains as well as assess intraand interspecies relationships within ecological fungal populations, including for Lecanicillium spp. (Hasan et al. 2011; Mitina et al. 2017). The RAPD technique utilises short random primers and generates repetitive or unique sequences in profiles, which primarily rely on homology between primers and template DNA (Kumari \& Thakur 2014). This approach does not require prior knowledge of the sequence, and only a limited quantity of genomic DNA is needed for PCR amplification.

In this study, we performed the internal transcribed spacer regions of the ribosomal RNA gene sequencing to identify six entomopathogenic fungal strains. To obtain new hybrid strains of Lecanicillium spp., protoplast fusion experiments were conducted using these strains and nit mutants as genetic markers. In addition, the genotypes were analysed using RAPD and the pathogenicity was assayed with aphids to compare the parental and fusant strains.

\section{MATERIALS AND Methods}

\section{STRAINS}

A total of six Lecanicillium spp. fungal strains (named $\mathrm{V} 1, \mathrm{~V} 2, \mathrm{~V} 3, \mathrm{~V} 4, \mathrm{~V} 5$, and V6) were isolated from the hemiptera group of insects (whiteflies, aphides and coccids) and herbivorous mites. These strains differed in virulence levels and were used as biocontrol agents (BCAs).

\section{GENOMIC DNA EXTRACTION AND FUNGAL STRAIN IDENTIFICATION}

Pure hyphae harvested from the strains were inoculated into $250 \mathrm{~mL}$ Erlenmeyer flasks containing Potato 
Dextrose Broth (PDB) and cultured at $26^{\circ} \mathrm{C}$ for 20 days. Genomic DNA from the parental and hybrid strains was isolated using a GenElute ${ }^{\mathrm{TM}}$ Plant Genomic DNA Miniprep Kit (Sigma-Aldrich, St. Louis, MO, USA), and DNA extraction procedures were performed according to the manufacturer's protocols. Two universal primer pairs (ITS4 and ITS5) were used to amplify the ITS gene from six strains (White et al. 1990) (Table 1). The gene was amplified in a $20 \mu \mathrm{L}$ reaction volume using an ABI PCR System 9700 cycler (Applied Biosystems, Foster City, USA) containing DNA sample $50 \mathrm{ng} / \mu \mathrm{L}, 10 \times \mathrm{PCR}$ buffer, $\mathrm{MgCl}_{2} 1.5 \mathrm{mM}$, dNTP $0.2 \mathrm{mM}, 1 \mu \mathrm{L}$ each of the forward and reverse primer $(10 \mu \mathrm{M}), 1 \mathrm{U}$ of Taq DNA polymerase (Therm Fisher Scientific, San Jose, CA, USA) and distilled water. The reaction condition was $94{ }^{\circ} \mathrm{C}$ for $4 \mathrm{~min}, 35$ cycles of $94{ }^{\circ} \mathrm{C}$ for $40 \mathrm{~s}, 50{ }^{\circ} \mathrm{C}$ for $40 \mathrm{~s}$ and $72{ }^{\circ} \mathrm{C}$ for 1 min, and followed by $72^{\circ} \mathrm{C}$ for $10 \mathrm{~min}$. The PCR products were analysed using agarose gel (1.2\%) electrophoresis. The ITS DNA fragments were sequenced using the BGI sequencing service (Beijing Genomics Institute, China) and homology search was performed using the Basic Local Alignment Search Tool (BLAST) programme provided by the National Center for Biotechnology Information (NCBI). (http://www.ncbi.nlm.nih.gov/blast).

\section{NIT MUTANT GENERATION AND PHYSIOLOGICAL PHENOTYPES}

Nit mutants were generated according to the method described by Korolev and Katan (1997) with slight modifications. The dosage of $\mathrm{KClO}_{3}$ was $50 \mathrm{~g} / \mathrm{L}$ in water agar chlorate (WAC) medium. Cultures exhibiting the physiological phenotypes of nit mutants were detected on five media containing different nitrogen sources according to the method described by Correll et al. (1987). The five media were nitrate medium (MM), nitrite medium, hypoxanthine medium, ammonium medium and uric acid medium. A dual culture technique was used to evaluate the complementation of nit mutants on MM plates.

\section{PROTOPLAST FORMATION AND FUSION}

Protoplast formation and fusion were performed according to the method of Aiuchi et al. (2008) with slight modifications. For protoplast formation, conidia from the parental nit mutants were harvested and treated with
$5 \mathrm{~mL}$ of Celluclast 1.5 L and Lysing Enzymes (SigmaAldrich, St. Louis, MO, USA) in a mixed enzyme solution for 4 to $5 \mathrm{~h}$ at $30^{\circ} \mathrm{C}$. The protoplasts were collected by centrifugation at $5000 \times \mathrm{g}$ for $5 \mathrm{~min}$. Each protoplast suspension was resuspended in sorbitol solution, further adjusted to approximately $10^{6}$ protoplasts $/ \mathrm{mL}$ and mixed, treated with an equal volume of prewarmed polyethylene glycol solution (30\%, PEG4000) and incubated at 30 ${ }^{\circ} \mathrm{C}$. After $15 \mathrm{~min}$, the fusion mixture was washed and centrifuged at $5000 \times \mathrm{g}$ for $5 \mathrm{~min}$, suspended in the sorbitol solution and inoculated on MM plates at $25{ }^{\circ} \mathrm{C}$ for purification. Prototrophic colonies grown on the $\mathrm{MM}$ plate were considered the result of gene complementation by protoplast fusion. Thus, each putative hybrid colony was sub-cultured on MM media for purification and sporulation. Only mycelia of colonies that demonstrated prototrophic growth on the MM plate were identified as single-spore isolated colonies (Parthiban et al. 2018). After approximately 20 generations of growth, stable isolates based on morphology were transferred onto Potato Sucrose Agar with Chitin medium (PSCA) at $25{ }^{\circ} \mathrm{C}$ for two weeks, and the quantity of aerial mycelia as well as the shape and colour of the colonies were observed and evaluated.

\section{FUSANT GENOMIC DNA ANALYSIS}

PCR amplifications of parental and fusant strains were carried out in an ABI PCR System 9700 cycler (Applied Biosystems, Foster City, USA). A premixed solution containing $2 \mu \mathrm{L}$ of $10 \times$ PCR Taq buffer with $\mathrm{KCl}, 1.5$ $\mathrm{mM} \mathrm{MgCl}, 0.2 \mathrm{mM} \mathrm{dNTP}$, and $1 \mathrm{U}$ of Taq polymerase (Therm Fisher Scientific, San Jose, CA, USA) was used for PCR amplification. A volume of $1 \mu \mathrm{L}$ of DNA template and $2 \mu \mathrm{L}$ of each individual primer were added into the premixed tubes where a total volume of $20 \mu \mathrm{L}$ was achieved by adding distilled water. The best two of nine primers OPA-02(TGCCGAGCTG) and OPH-13(GACGCCACAC) were used for RAPD-PCR amplification, the reaction condition was $94{ }^{\circ} \mathrm{C}$ for 5 min, 45 cycles of $94^{\circ} \mathrm{C}$ for $1 \mathrm{~min}, 37^{\circ} \mathrm{C}$ for $1 \mathrm{~min} 30 \mathrm{~s}$, and $72{ }^{\circ} \mathrm{C}$ for $2 \mathrm{~min}$, followed by $72^{\circ} \mathrm{C}$ for $10 \mathrm{~min}$ (Table 1). Finally, the amplification products were stored at 4 ${ }^{\circ} \mathrm{C}$ and the RAPD band patterns were analysed using Quantity One software. Phylogenetic trees derived were constructed using the Unweighted Pair Group Method with Arithmetic Mean (UPGMA) method. 
TABLE 1. Primers used in this study, (a) Fungal strain identification and analysis (b) Genomic DNA RAPD analysis

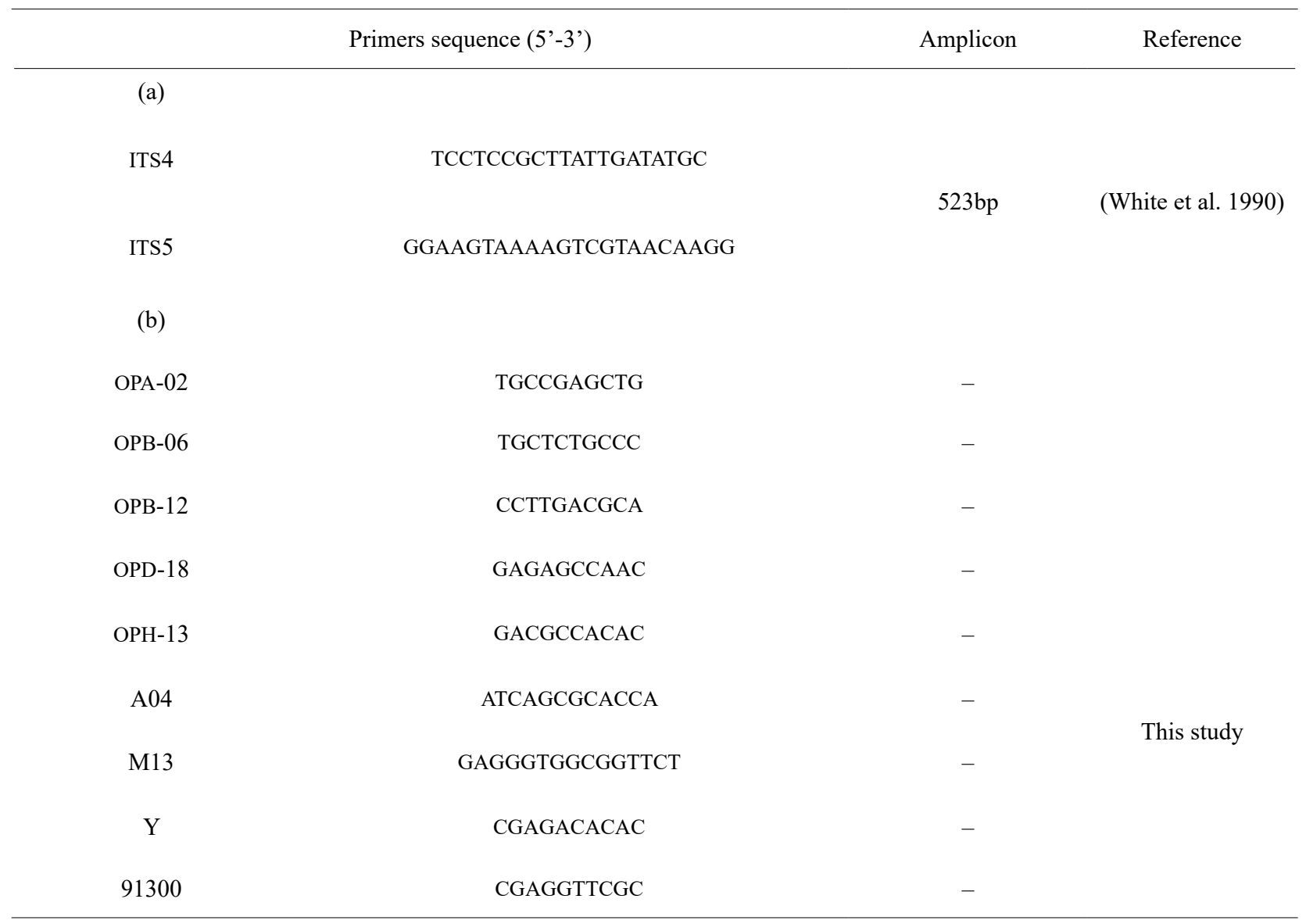

(1) The sizes of (b) were not shown because these PCRs indicated RAPD banding pattern. (2) All amplifications were undertaken for hot start

\section{PATHOGENICITY OF PARENTAL AND FUSANT STRAINS AGAINST APHIDS}

Pathogencity levels of parental and fusant strains were assayed using nymphs of aphids (Myzus persica) according to the method described by Akbari et al. (2014). Aphids were obtained from the greenhouse Chinese cabbage field at Heilongjiang Academy of Agricultural Science, China. Aphids were treated with $0.05 \%(\mathrm{v} / \mathrm{v})$ Tween 80 as control. Each treatment had three replicates with 50 aphids per replicate. The mortality of aphids was recorded every $24 \mathrm{~h}$ up to 7 days. The median lethal concentration $\left(\mathrm{LC}_{50}\right)$ and median survival time $\left(\mathrm{LT}_{50}\right)$ of the treated aphids were calculated. All statistical analyses were performed using SPSS 21.0 (SPSS Inc., Chicago, IL,
USA). The significance level of $\mathrm{P}<0.05$ was accepted (Wang et al. 2017).

\section{RESUlTS AND DISCUSSION}

\section{IDENTIFICATION OF ENTOMOPATHOGENIC FUNGAL STRAINS}

Colonies of the parental strains cultivated on PDA medium were white and thin in appearance with short aerial (V4), atypical (V1 and V2) or cottony mycelia (V3, V5 and V6) (Figure 1). The colour and microscopic observation of parents V1-V6 were identical to known Lecanicillium spp. cultures (Gams \& Zare 2001; Kim et al. 2007; Wang et al. 2017). The ITS rDNA sequence 
data of V1-V6 strains were analysed using the BLAST programme (NCBI). The results showed that the isolates of V1, V3 and V5 had 98, 98 and 99\% nucleotide identity with $L$. lecanii, respectively, while V2, V4 and V6 isolates showed 99, 100 and $98 \%$ nucleotide identity with $L$. attenuatum Zare and Gams. Therefore, morphological identification combined with molecular analysis confirmed that the three fungal isolates belonged to $L$. lecanii, whereas the other three isolates belonged to $L$. attenuatum Zare and Gams (Gene Bank Accession No. MH231308-MH231313).

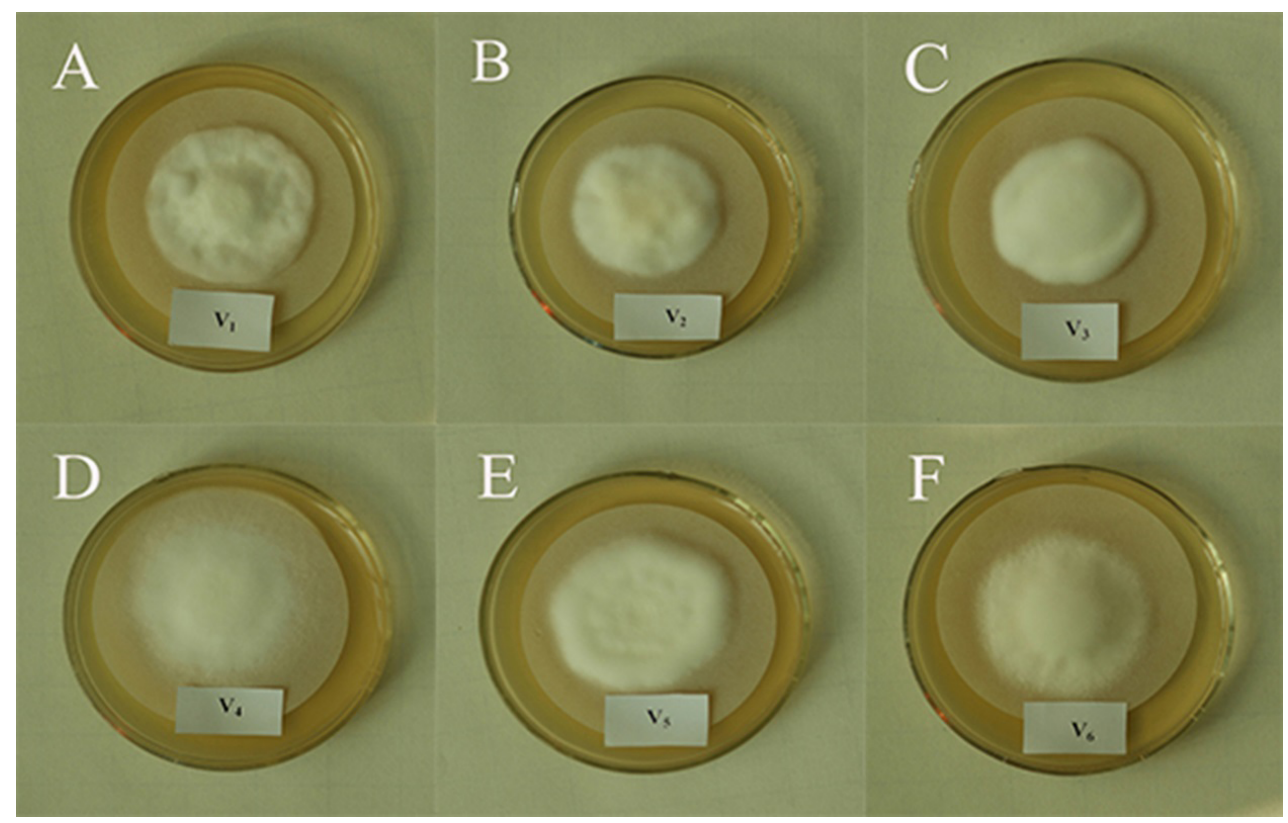

FIGURE 1. Colony morphology of six parental strains cultivated on PDA medium A:V1; B:V2; C:V3; D:V4; E:V5; F:V6

\section{NIT MUTANT GENERATION AND DIFFERENT PHYSIOLOGICAL PHENOTYPES}

Colonies from the six strains were extremely restricted on WAC medium. After incubation for 30 days, fast-growing and thin colonies with sectors of chlorate resistance were visible. When these colonies were transferred to $\mathrm{MM}$ plates, $56.67,61.53,76.19,64.62,87.00$, and $83.00 \%$ of the chlorate-resistant sectors isolated from V1, V2, V3, V4, V5, and V6, respectively, exhibited thin, expansive growth with non-aerial mycelia. These sectors recognised as nit mutants were divided into four phenotypic classes (nit1, nit2, nit3 and NitM) according to an evaluation of colony morphology on five media containing different nitrogen sources (Correll et al. 1987).

However, in this study, nit1, nit3, and NitM, but not nit2, were detected on WAC medium. The proportions of nit 1 and NitM were 94.12 and 5.88\% from V1, 81.25 and $18.75 \%$ from $\mathrm{V} 2,91.67$ and $8.33 \%$ from $\mathrm{V} 3,83.33$ 
and $16.67 \%$ from $\mathrm{V} 4$, and 95.40 and $4.60 \%$ from V5. Meanwhile, nit $\mathrm{M}$ was not obtained from V6, and the proportions of nit1 and nit3 from V6 were 98.80 and $1.20 \%$, respectively (Table 2). V1-7 (nit1), V1-1 (NitM) (derived from $\mathrm{V} 1$ ), V2-20 (nit1), V2-5 (NitM) (derived from V2), V3-27 (nit1), V3-18 (NitM) (derived from V3),
V4-9 (nit1), V4-2 (NitM) (derived from V4), V5-9 (nit1), V5-12 (NitM) (derived from V5), V6-37 (nit1), and V636 (nit3) (derived from V6) were selected for protoplast fusion experiments. Complementation tests demonstrated that all different phenotype combinations of the parental nit mutants were incompatible on MM medium.

TABLE 2. Frequency and phenotypes of nit mutants recovered from six isolates of Lecanicillium spp. on WAC medium

\begin{tabular}{|c|c|c|c|c|c|c|c|}
\hline \multirow{2}{*}{ Parental strains } & \multirow{2}{*}{$\begin{array}{c}\text { No. of } \\
\text { inoculations }\end{array}$} & \multirow{2}{*}{$\begin{array}{l}\text { No. of } \\
\text { sectors }\end{array}$} & \multirow{2}{*}{$\begin{array}{l}\text { No. of nit } \\
\text { mutants }\end{array}$} & \multirow{2}{*}{$\begin{array}{c}\text { Nit mutants } \\
(\%)\end{array}$} & \multicolumn{3}{|c|}{ Phenotypes of nit mutants (\%) } \\
\hline & & & & & nit1 & nit3 & $N i t \mathrm{M}$ \\
\hline V1 & 100 & 30 & 17 & 56.67 & 94.12 & 0.00 & 5.88 \\
\hline $\mathrm{V} 2$ & 100 & 52 & 32 & 61.53 & 81.25 & 0.00 & 18.75 \\
\hline $\mathrm{V} 3$ & 100 & 63 & 48 & 76.19 & 91.67 & 0.00 & 8.33 \\
\hline V4 & 100 & 65 & 42 & 64.62 & 83.33 & 0.00 & 16.67 \\
\hline V5 & 100 & 100 & 87 & 87.00 & 95.40 & 0.00 & 4.60 \\
\hline V6 & 100 & 100 & 83 & 83.00 & 98.80 & 1.20 & 0.00 \\
\hline
\end{tabular}

\section{PROTOPLAST FUSION OF NIT MUTANTS}

In preliminary experiments, there were no back mutations in each nit mutant after three inoculations (four MM plates per replication). Through the experiments, we obtained $24,4,44,18,10,16,32,16$, and 12 (a total of 176) stable hybrid strains from $\mathrm{V} 1-7$ (V1, nit1) $\times \mathrm{V} 2-5$ (V2, NitM), V1-1 (V1, NitM)×V4-9 (V4, nit1), V1-1 (V1, NitM) $\times \mathrm{V} 6-37(\mathrm{~V} 6$, nit1), V2-5 (V2, NitM) $\times \mathrm{V} 3-27$ (V3, nit1), V2-20 (V2, nit1) $\times \mathrm{V} 5-12(\mathrm{~V} 5$, Nit $\mathrm{M}), \mathrm{V} 3-18$ $(\mathrm{V} 3$, NitM) $\times \mathrm{V} 4-9(\mathrm{~V} 4$, nit1 $), \mathrm{V} 3-18(\mathrm{~V} 3$, NitM $) \times \mathrm{V} 6-37$ (V6, nit1), V4-2 (V4, NitM) $\times \mathrm{V} 5-9(\mathrm{~V} 5$, nit1) and V5-12 (V5, NitM) $\times \mathrm{V} 6-36(\mathrm{~V} 6$, nit3), respectively. These strains were termed $\mathrm{V}_{12} 1-24, \mathrm{~V}_{14} 1-4, \mathrm{~V}_{16} 1-44, \mathrm{~V}_{23} 1-18, \mathrm{~V}_{25} 1-10$, $\mathrm{V}_{34} 1-16, \mathrm{~V}_{36} 1-32, \mathrm{~V}_{45} 1-16$ and $\mathrm{V}_{56} 1-12$, respectively. The frequency of protoplast fusion in this study was appropriate for obtaining the number of products required for subsequent fusant screening (fusion frequency of 10$\left.{ }^{6}\right)$, with the exception of the V1-1 (V1, NitM) $\times$ V4-9 (V4, nit1) combination (fusion frequency of $10^{-8}$ ).

Fusant colony morphology was evaluated on PSCA medium, and rough colonies were not stable. After approximately 10 to 20 transfers, the colonies stabilised and appeared flat without sectors. The nit mutants derived from parental strains produced thin flat colonies with short aerial mycelia, and all strains showed white colonies without sectors. However, the colonies of the fusant strains were clearly distinguishable from their parental strains based on morphology. These colonies were roughly grouped into the following four type namely dense colonies with aerial mycelia (A, B and C), thin colonies with mycelia (D and $\mathrm{E}$ ), thin colonies with short mycelia ( $F$ and $\mathrm{G})$, double circle-type colonies $(\mathrm{H})$ and atypical growth colonies (I) (Figure 2). 


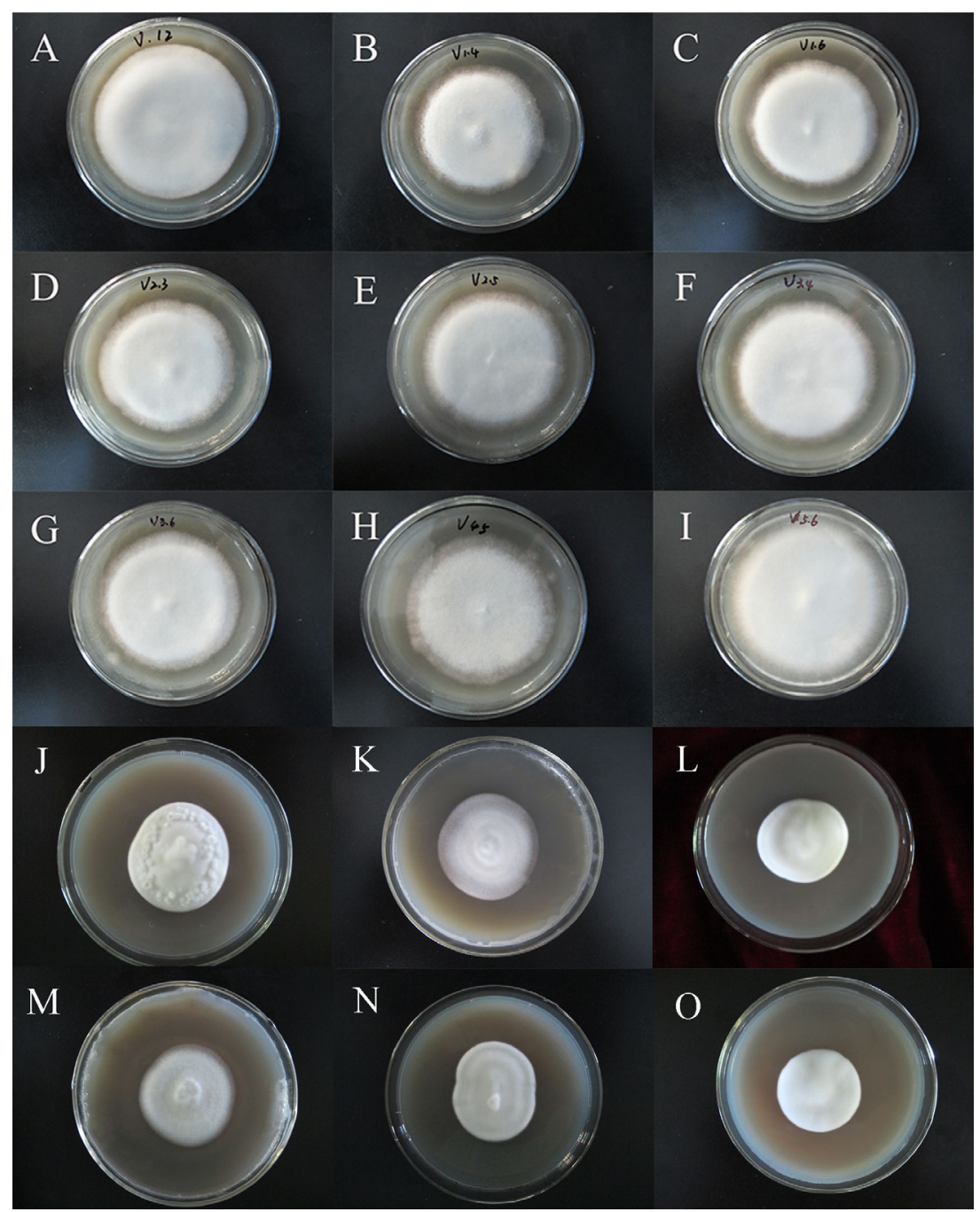

FIGURE 2. Colony morphology of 14-day-old parental and fusant strains on PSCA. A: $\mathrm{V}_{12}-10$, dense colony with aerial mycelia. $\mathrm{B}: \mathrm{V}_{14}-3$, dense colony. $\mathrm{C}: \mathrm{V}_{16}-4$, dense colony growth similar to that of $\mathrm{V}_{1}$. $\mathrm{D}: \mathrm{V}_{23}-6$, thin colony similar to that of $\mathrm{V}_{2} . \mathrm{E}: \mathrm{V}_{25}-8$, thin colony with aerial mycelia. $\mathrm{F}: \mathrm{V}_{34}-14$, thinner colony than the parental colony. $\mathrm{G}: \mathrm{V}_{36}-5$, thin colony with short aerial mycelia. $\mathrm{H}$ : $\mathrm{V}_{45}-16$, double circle-type colony. I: $\mathrm{V}_{56}{ }^{-7}$, atypical growth-type colony. J: V1. K: V2. L: V3. M: V4. N: V5. O: V6

GENOMIC DNA ANALYSIS OF HYBRID STRAINS

By optimising reaction conditions and screening random primers, we identified a significant difference in the RAPD pattern between the parental and hybrid strains of Lecanicillium spp. Data from the optimised RAPD amplification conditions are presented in Figure 3. Out of the 60 RAPD primers screened, 9 primers (Results of the best two of the nine primers were shown in Figure 3) were selected for further analysis. The RAPD banding patterns of the parental and hybrid strains of Lecanicillium spp., determined using the OPA-02 and OPH-13 primers, were illustrated in Figure 3(a) and 3(b). Nine primers generated a total of 790 reproducible, distinct bands ranging from 200 to $3000 \mathrm{bp}$ among the parental and hybrid strains. The 
number of bands per primer was 99 for primer OPA-02, 49 for primer OPB-06, 60 for primer OPB-12, 105 for primer OPD-18, 120 for primer Y, 70 for primer 91300, 123 for primer A04, 104 for primer M13 and 60 for primer OPH13 , with an average of 5.85 polymorphic bands per primer. Out of the 790 bands, $660(83.55 \%)$ were monomorphic and 130 bands (16.45\%) were polymorphic, showing a low to moderate degree of polymorphism. Nine and five different RAPD profiles were produced using OPA-02 and $\mathrm{OPH}-13$ primers, respectively, and most of the strains appeared to have common bands. The OPA-02 primer produced a total of nine prominent bands with the sizes of $2600,1600,1450,950,850,750,550,475$ and $360 \mathrm{bp}$ (Figure 3(a)). By contrast, the OPH-13 primer produced a total of five prominent bands with the sizes of 2800, 1350, 1000, 600, and $450 \mathrm{bp}$ (Figure 3(b)). The hybrid strains in lanes $7,8,9,10,11,12,13,14$, and 15 had different banding patterns compared with the parental strains in lanes 1,2 , $3,4,5$, and 6 with the OPA-02 and OPH-13 primers. Of the 15 parental and hybrid strains, the maximum number of bands was observed in lane $15\left(\mathrm{~V}_{56}{ }^{-7}\right)$. Lanes $6\left(\mathrm{~V}_{6}\right)$ and $12\left(\mathrm{~V}_{34}-14\right)$ demonstrated banding profiles with the $\mathrm{OPH}-13$ primer that were different from the remaining strains (Figure 3(b)).

Dendrogram analysis with the OPA-02 primer (Figure 3(c)) showed that all of the strains were divided into four major clades. The most prominent clade was clade I, which contained six different hybrid strains (\#10: $\mathrm{V}_{23}-6$; \#11: $\mathrm{V}_{25}-8$; \#12: $\mathrm{V}_{34}-14 ; \# 13: \mathrm{V}_{36}-5$; \#14: $\mathrm{V}_{45}-16$ and $\# 15: \mathrm{V}_{56}-7$ ). Clade III contained three strains (\#7: $\mathrm{V}_{12}-10$; $\# 8: \mathrm{V}_{14}-3$ and $\left.\# 9: \mathrm{V}_{16}-4\right)$. These strains had similar banding patterns, as shown in Figure 3(a). These results showed clear homogeneity among different hybrid strains. All three strains were derived from the same parental strains \#1:V1. Clades II and IV presented two (\#2: V2 and \#3: V3) and four strains (\#1: V1, \#4: V4, \#5: V5 and \#6: V6), respectively. All of these strains were parental strains. The five major clades were shown in Figure 3(d), using the $\mathrm{OPH}-13$ primer. The most prominent clade was clade $\mathrm{V}$, which contained six different hybrid strains (\#1: V1, \#2: V2, \#3: V3, \#4: V4, \#7: $\mathrm{V}_{12}-10$ and \#8: $\mathrm{V}_{14}-3$ ). Clade III contained three strains (\#9: $\mathrm{V}_{16}-4, \# 10: \mathrm{V}_{23}-6$ and \#11: $\mathrm{V}_{25}-8$ ). Among these, the \#10 and \#11 hybrid strains were derived from the same parental strain, V2. Clades I (\#12: $\left.\mathrm{V}_{34}-14, \# 15: \mathrm{V}_{56}-7\right)$, II (\#5: V5, \#14: $\left.\mathrm{V}_{45}-16\right)$ and IV (\#6: V6, \#13: $\left.V_{36}-5\right)$ were each composed of two strains. Clades I and IV were represented by lanes 6 and 12 in the gel image and showed different RAPD banding patterns. All of these results indicated that genes in the hybrid strains resulting from protoplast fusion underwent recombination and RAPD analysis was feasible to confirm protoplast fusants. (a)

(b)

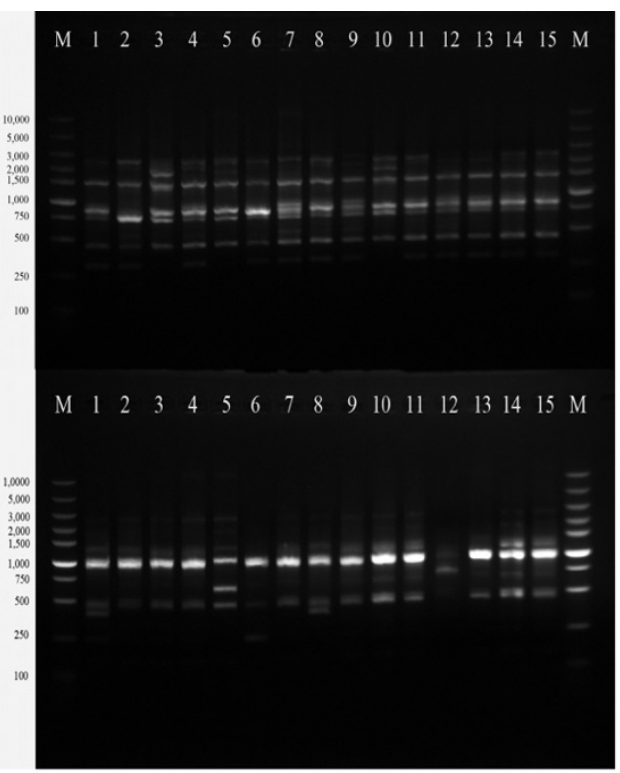

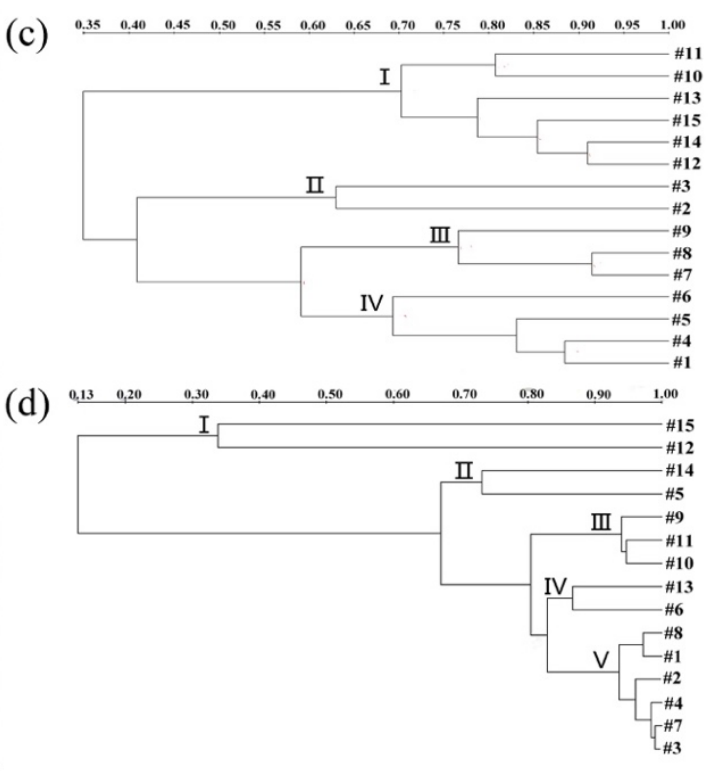

FIGURE 3. RAPD profiling of 15 Lecanicillium spp. using the (a) OPA-02 primer; (b) OPH-13 primer, M: 100-bp marker (BioLabs); Lane 1: V1; Lane 2: V2; Lane 3: V3; Lane 4: V4; Lane 5: V5; Lane 6: V6; Lane 7: $\mathrm{V}_{12}-10$; Lane 8: $\mathrm{V}_{14}-3$; Lane 9: $\mathrm{V}_{16}-4$; Lane 10: $\mathrm{V}_{23}-6$; Lane 11: $\mathrm{V}_{25}-8$; Lane 12: $\mathrm{V}_{34}-14$; Lane 13: $\mathrm{V}_{36}-5$; Lane 14: $\mathrm{V}_{45}-16$; Lane 15: $\mathrm{V}_{56}-7$. Cluster analysis of the RAPD (c) OPA-02 primer; (d) OPH-13 primer with the V1 to V6 and hybrid strains using the UPGMA method with Quantity One software. \#1: V1; \#2: V2; \#3: V3; \#4: V4; \#5: V5; \#6: V6; \#7: $\mathrm{V}_{12}-10$; \#8: $\mathrm{V}_{14}-3$; \#9:

$$
\mathrm{V}_{16}-4 ; \# 10: \mathrm{V}_{23}-6 ; \# 11: \mathrm{V}_{25}-8 ; \# 12: \mathrm{V}_{34}-14 ; \# 13: \mathrm{V}_{36}-5 ; \# 14: \mathrm{V}_{45}-16 ; \# 15: \mathrm{V}_{56}-7
$$




\section{PATHOGENICITY OF PARENT AND FUSANT STRAINS} AGAINST APHIDS

In addition to the differences observed in colony morphologies and RAPD profiles as compared to their parental strains, several fusants showed enhanced virulence against aphids. The bioassay results indicated that the fusants were much more efficient in virulence than the parental strains. The $\mathrm{LC}_{50}$ and $\mathrm{LT}_{50}$ values were shown in Figure 4. The different groups of parent and fusant strains were separated by dotted lines in the figure. The $\mathrm{LC}_{50}$ values of the parental strains against aphids required the concentrations of $7.48 \pm 0.04 \times 10^{5}, 4.38 \pm 0.02 \times 10^{5}$, $0.95 \pm 0.01 \times 10^{5}, 2.84 \pm 0.02 \times 10^{5}, 6.49 \pm 0.03 \times 10^{5}$ and $1.05 \pm 0.04 \times 10^{6}$ conidia/mL, respectively $(\# 1: \mathrm{V} 1, \# 2$ : $\mathrm{V} 2$, \#3: V3, \#4: V4, \#5: V5 and \#6: V6) (Figure 4(a)). The $\mathrm{LC}_{50}$ values of the fusant strains were $4.02 \pm 0.03 \times 10^{5}\left(\# 7: \mathrm{V}_{12}-\right.$ 10; compared with parental strains \#1: V1 and \#2: V2), $2.23 \pm 0.01 \times 10^{5}\left(\# 8: \mathrm{V}_{14}-3\right.$; compared with parental strains
$\# 1$ : V1 and \#4: V4), $6.35 \pm 0.03 \times 10^{5}\left(\# 9\right.$ : $\mathrm{V}_{16}-4$; compared with parental strains \#1: V1 and \#6: V6), $0.81 \pm 0.02 \times 10^{5}$ (\#10: $\mathrm{V}_{23}-6$; compared with parental strains \#2: V2 and \#3: V3), 3.32 $\pm 0.02 \times 10^{5}\left(\# 11: \mathrm{V}_{25}-8\right.$; compared with parental strains \#2: V2 and \#5: V5), $0.88 \pm 0.04 \times 10^{5}$ (\#12: $\mathrm{V}_{34}-14$; compared with parental strains \#3: V3 and \#4: V4), $0.78 \pm 0.04 \times 10^{5}\left(\# 13: \mathrm{V}_{36}-5\right.$; compared with parental strains \#3: V3 and \#6: V6), 2.12 $\pm 0.05 \times 10^{5}\left(\# 14: \mathrm{V}_{45}-16\right.$; compared with parental strains \#4: V4 and \#5: V5) and $5.52 \pm 0.03 \times 10^{5}\left(\# 15: \mathrm{V}_{56}{ }^{-7}\right.$; compared with parental strains \#5: V5 and \#6: V6) conidia/mL, respectively $(\mathrm{P}<0.05)$. The value of $\mathrm{LT}_{50}$ were $4.12 \pm 0.02\left(\# 7: \mathrm{V}_{12}-10\right), 3.18 \pm 0.03$ (\#8: $\left.\mathrm{V}_{14}-3\right), 4.20 \pm 0.02\left(\# 9: \mathrm{V}_{16}-4\right), 3.88 \pm 0.01\left(\# 10: \mathrm{V}_{23}-6\right)$, 4.22 $\pm 0.02\left(\# 11: \mathrm{V}_{25}-8\right), 3.95 \pm 0.04\left(\# 12: \mathrm{V}_{34}-14\right), 4.10 \pm 0.01$ $\left(\# 13: \mathrm{V}_{36}-5\right), 4.03 \pm 0.06\left(\# 14: \mathrm{V}_{45}-16\right)$, and 4.16 \pm 0.02 (\#15: $\mathrm{V}_{56}{ }^{-7)}$ ) days for fusants, which were significantly shorter compared to $4.51 \pm 0.01,5.48 \pm 0.05,4.25 \pm 0.04,4.11 \pm 0.02$, $4.48 \pm 0.02,4.92 \pm 0.03$ days for parents \#1:V1 to \#6: V6, respectively $(\mathrm{P}<0.05)$ (Figure $4(\mathrm{~b})$ ).
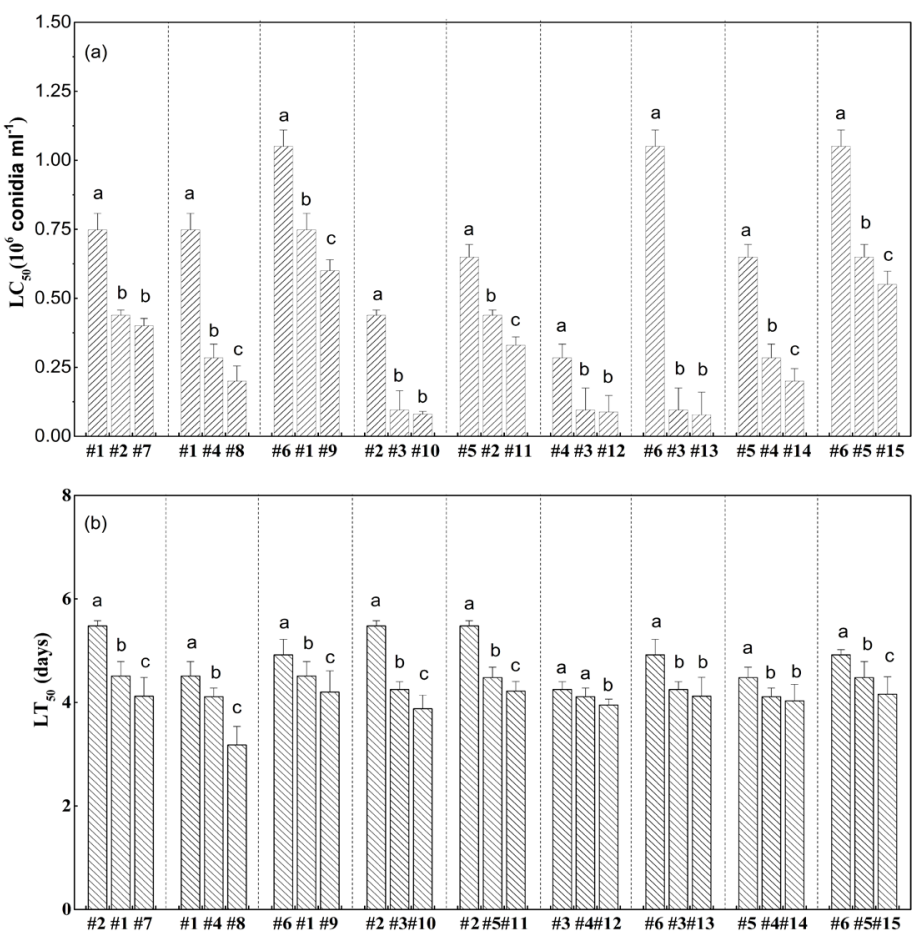

FIGURE 4. Pathogenicity of parents and fusants against aphids. (a) The $\mathrm{LC}_{50}$ of aphids infected with parents and fusants. (b) The $\mathrm{LT}_{50}$ of aphids infected with a concentration of $1 \times 10^{8}$ conidia/mL parents and fusants. \#1: V1; \#2: V2; \#3: V3; \#4: V4; \#5: V5; \#6: V6; \#7: $\mathrm{V}_{12}-10$; \#8: $\mathrm{V}_{14}-3$; \#9: $\mathrm{V}_{16}-4$; \#10: $\mathrm{V}_{23}-6$; \#11: $\mathrm{V}_{25}{ }^{-}$ 8; \#12: $\mathrm{V}_{34}-14 ; \# 13: \mathrm{V}_{36}-5 ; \# 14: \mathrm{V}_{45}-16 ; \# 15: \mathrm{V}_{56}-7$. Different lowercase letters indicate significant differences at 0.05 level 
To control agricultural insects more efficiently, further research on entomopathogenic fungal strain improvement by protoplast fusion is required. Currently, studies are primarily focused on developing intergeneric or interspecific fusants between various species of fungi with good biocontrol effects (El-Fadly et al. 2018; Lalithakumari 2019). Hybrid strains acquire enhanced virulence, a wider host range and higher rhizosphere competence as a result of such genetic recombination (Couteaudier et al. 1996; Hirpara \& Gajera 2018; Inderbitzin et al. 2011).

In the present study, based on morphological observations and ITS gene sequencing analyses, two fungal isolates were found to belong to different Lecanicillium spp. (L. lecanii and L. attenuatum). Therefore, the protoplast fusion experiments with $(\mathrm{V} 1, \mathrm{~V} 3$ or V5) $\times(\mathrm{V} 2, \mathrm{~V} 4$ or V6) presumably involved intraspecific hybridisation. Moreover, many parameters are critical for protoplast generation, including the composition and structure of the cell wall among different fungal species and the composition, activity and actions of mixed lytic enzymes, osmotic stabilisers and other factors. Thus, optimisation of the experimental conditions is essential, as a good experimental system is the foundation of fungal improvement and genetic manipulation (Wu \& Chou 2019). In previous reports, the fusion frequency of intraspecific hybridisation ranged from $10^{-7}$ to $10^{-4}$ in Beauveria and Metarhizium (Couteaudier et al. 1996; Muralidhar \& Panda 2000). The number of fusion strains produced by the V1-1 (V1, NitM) and V4-9 (V4, nit1) combination gave the lowest number of hybrids (only four were obtained) compared to that of the other combinations in this study. We assumed that these results were attributed to genetic barriers between different species (Abbott et al. 2013; Strom \& Bushley 2016). Colony morphology and spore size have been used as fusant markers to identify intergeneric or interspecific fusion products, given the significant differences in colony morphology among species (Parthiban et al. 2018). Aiuchi et al. (2008) showed that the different colony morphologies of hybrid strains were primarily attributable to heterokaryons generated in the final protoplast suspension, and only prototrophic colonies developed from homokaryons grow on MM medium. Thus, the authors were easily able to distinguish the fusants from nit mutants (non-fusing) and homokaryons (self-fusing) (Strom \& Bushley 2016).

PCR with specific primers has been developed and applied to different fields by other researchers (Kumari \& Thakur 2014; Modi et al. 2017). In particular, earlier
RAPD profiling for Lecanicillium spp. has been reported and successfully used to differentiate subspecies of $L$. attenuatum, L. lecanii, L. longisporum, L. muscarium, and L. nodulosum (Enkerli \& Widmer 2010; Lee et al. 2015; Mitina et al. 2008; Oborník et al. 2000). In this work, our results indicated that the RAPD protocol used was able to detect genetic diversity in the parental and hybrid strains. Although there are certain disadvantages on RAPD in terms of reproducibility, primer design, amplification and other aspects, this technique is still a convenient, economical, and rapid method that provides information on genomic variability at the sub-species level.

Our results also showed that the median lethal concentration $\left(\mathrm{LC}_{50}\right)$ for nine fusant strains were lower than that for parental strains under laboratory conditions. The $\mathrm{LC}_{50}$ value of fusants and parental strains applied to aphids was $0.78 \pm 0.04 \times 10^{5}$ to $6.35 \pm 0.03 \times 10^{5}$ conidia/ $\mathrm{mL}$ and $0.95 \pm 0.01 \times 10^{5}$ to $1.05 \pm 0.04 \times 10^{6}$ conidia $/ \mathrm{mL}$, respectively. Previous studies demonstrated that $L$. lecanii and L. attenuatum strains can be highly virulent towards aphids mostly at $10^{6}$ to $10^{8}$ conidia/mL (Asi et al. 2009; Kim et al. 2008). The median survival time $\left(\mathrm{LT}_{50}\right)$ for fusant strains were also reduced compared to that for parental strains. The values observed were in the range of $3.18 \pm 0.03$ to $4.22 \pm 0.02$ and $4.11 \pm 0.02$ to $5.48 \pm 0.05$ days, respectively. Thus, we have produced new, more virulent hybrid Lecanicillium spp. strains via intraspecific protoplast fusion and some of these strains might be useful as biological control agents in field applications.

\section{CONCLUSION}

The protoplast fusion technique provides a feasible method for strain improvement, and various molecular techniques are available as informative DNA markers for entomopathogenic fungi. In our study, the genetic exchanges detected have improved the pathogenicity efficiency. We used six strains of Lecanicillium spp. to develop superior new hybrid strains of entomopathogenic fungi via intraspecific protoplast fusion while providing a prospective procedure to obtain novel microorganisms as biocontrol agents.

\section{ACKNOWLEDGEMENTS}

This work was supported by the Research Projects Fund at the Academy Level of Heilongjiang Academy of Agricultural Sciences (NO. 2017ZC09); and the National Key Research and Development Plan Research Fund: Screening and evaluation of new biocontrol agent (NO. 2017YFD0201108). 


\section{REFERENCES}

Abbott, R., Albach, D., Ansell, S., Arntzen, J.W., Baird, S.J., Bierne, N., Boughman, J., Brelsford, A., Buerkle, C.A., Buggs, R., Butlin, R.K., Dieckmann, U., Eroukhmanoff, F., Grill, A., Cahan, S.H., Hermansen, J.S., Hewitt, G., Hudson, A.G., Jiggins, C., Jones, J., Keller, B., Marczewski, T., Mallet, J., Martinez-Rodriguez, P., Most, M., Mullen, S., Nichols, R., Nolte, A.W., Parisod, C., Pfennig, K., Rice, A.M., Ritchie, M.G., Seifert, B., Smadja, C.M., Stelkens, R., Szymura, J.M., Vainola, R., Wolf, J.B.W. \& Zinner, D. 2013. Hybridization and speciation. Journal of Evolutionary Biology 26(2): 229-246.

Aiuchi, D., Inami, K., Kuramochi, K., Koike, M., Sugimoto, M., Tani, M. \& Shinya R. 2008. A new method for producing hybrid strains of the entomopathogenic fungus Verticillium lecanii (Lecanicillium spp.) through protoplast fusion by using nitrate non-utilizing (nit) mutants. Micologia Aplicada International 20(1): 1-16.

Akbari, S., Ali Safavi, S. \& Ghosta, Y. 2014. Efficacy of Beauveria bassiana (Blas.) Vuill. against cabbage aphid Brevicoryne brassicae L. (Hem.: Aphididae) in laboratory condition. Archives of Phytopathology and Plant Protection 47(12): 1454-1458.

Almeida, J.E.M., Leite, L.G. \& Batista Filho, A. 2019. Natural Enemies of Insect Pests in Neotropical Agroecosystems. New York: Springer. pp. 223-233.

Asi, M.R., Bashir, M.H., Afzal, M. \& Imran, S. 2009. Effect of conidial concentration of entomopathogenic fungi on mortality of cabbage aphid, Brevicoryne brassicae L. Pakistan Journal of Life and Social Sciences 2(7): 175-180.

Correll, J.C., Klittich, C.R.J. \& Leslie, J.F. 1987. Nitrate nonutilizing mutants of Fusarium oxysporum and their use in vegetative compatibility tests. Phytopathology 77: 16401646.

Couteaudier, Y., Viaud, M. \& Riba, G. 1996. Genetic nature, stability, and improved virulence of hybrids from protoplast fusion in Beauveria. Microbial Ecology 32(1): 1-10.

Dahlmann, T.A., Böhm, J., Becker, K. \& Kück, U. 2015. Sexual recombination as a tool for engineering industrial Penicillium chrysogenum strains. Current Genetics 61(4): 679-683.

El-Fadly, G., Abou-Shoshah, A. \& Rehan, M. 2018. Interspecific Streptomyces protoplast fusants as biological control agents. Catrina: The International Journal of Environmental Sciences 4(2): 37-44.

Enkerli, J. \& Widmer, F. 2010. Molecular ecology of fungal entomopathogens: Molecular genetic tools and their applications in population and fate studies. BioControl 55(1): 17-37.

Fang, W., Lu, H.L., King, G.F. \& Leger, R.J.S. 2014. Construction of a hypervirulent and specific mycoinsecticide for locust control. Scientific Reports 4(1): 7345.

Gams, W. \& Zare, R. 2001. A revision of Verticillium Sect. Prostrata. III. Genetic classification. Nova Hedwigia 72(34): $329-337$.
Hasan, S., Singh, R.I. \& Singh, S.S. 2011. Development of transformation system of Verticillium lecanii (Lecanicillium spp.) (Deuteromycotina: hyphomycetes) based on nitrate reductase gene of Aspergillus nidulans. Indian Journal of Microbiology 51(3): 390-395.

Hassan, M.M. 2014. Influence of protoplast fusion between two Trichoderma spp. on extracellular enzymes production and antagonistic activity. Biotechnology and Biotechnological Equipment 28(6): 1014-1023.

Hirpara, D.G. \& Gajera, H.P. 2018. Molecular heterozygosity and genetic exploitations of Trichoderma inter-fusants enhancing tolerance to fungicides and mycoparasitism against Sclerotium rolfsii Sacc. Infection, Genetics and Evolution: Journal of Molecular Epidemiology and Evolutionary Genetics in Infectious Diseases 66: 26-36.

Inderbitzin, P., Davis, R.M., Bostock, R.M. \& Subbarao, K.V. 2011. The ascomycete Verticillium longisporum is a hybrid and a plant pathogen with an expanded host range. PloS ONE 6(3): e18260.

Kim, J.J., Goettel, M.S. \& Gillespie, D.R. 2007. Potential of Lecanicillium species for dual microbial control of aphids and the cucumber powdery mildew fungus, Sphaerotheca fuliginea. Biological Control 40(3): 327-332.

Kim, H.Y., Lee, H.B., Kim, Y.C. \& Kim, I.S. 2008. Laboratory and field evaluations of entomopathogenic Lecanicillium attenuatum CNU-23 for control of green peach aphid (Myzus persicae). Journal of Microbiology and Biotechnology 18(12): 1915-1918.

Korolev, N. \& Katan, T. 1997. Improved medium for selecting nitrate-nonutilizing (nit) mutants of Verticillium dahliae. Phytopathology 87(10): 1067-1070.

Kumari, N. \& Thakur, S.K. 2014. Randomly amplified polymorphic DNA - A brief review. American Journal of Animal and Veterinary Sciences 9(1): 6-13.

Lalithakumari, D. 2019. Fungal Protoplast: A Biotechnological Tool. Boca Raton: CRC Press.

Lee, W.W., Shin, T.Y., Bae, S.M. \& Woo, S.D. 2015. Screening and evaluation of entomopathogenic fungi against the green peach aphid, Myzus persicae, using multiple tools. Journal of Asia-Pacific Entomology 18(3): 607-615.

Leland, J. \& Gore, J. 2017. Microbial Control of Insect and Mite Pests. Oxford: Academic Press. pp. 185-197.

Mitina, G.V., Kazartsev, I., Vasileva, A. \& Yli Mattila, T. 2017. Multilocus genotyping based species identification of entomopathogenic fungi of the genus Lecanicillium (= Verticillium lecanii s.1.). Journal of Basic Microbiology 57(11): 950-961.

Mitina, G.V., Mikhailova, L.A. \& Yli-Mattila, T. 2008. RAPD-PCR, UP-PCR and rDNA sequence analyses of the entomopathogenic fungus Verticillium lecanii and its pathogenicity towards insects and phytopathogenic fungi. Archives of Phytopathology and Plant Protection 41(2): 113-128.

Modi, A., Gajera, B., Subhash, N. \& Kumar, N. 2017. Evaluation of clonal fidelity of micropropagated date palm by random amplified polymorphic DNA (RAPD). In Date Palm 
Biotechnology Protocols Volume II. New York: Humana Press. pp. 81-89.

Muralidhar, R.V. \& Panda, T. 2000. Fungal protoplast fusion: A revisit. Bioprocess and Biosystems Engineering 22(5): 429-431.

Nyasani, J.O., Subramanian, S., Poehling, H.M., Maniania, N.K., Ekesi, S. \& Meyhöfer, R. 2015. Optimizing western flower thrips management on French beans by combined use of beneficials and imidacloprid. Insects 6(1): 279-296.

Oborník, M., Klíc, M. \& Zizka, L. 2000. Genetic variability and phylogeny inferred from random amplified polymorphic DNA data reflect life strategy of entomopathogenic fungi. Canadian Journal of Botany 78(9): 1150-1155.

Parthiban, P., Baskaran, R.K.M., Chinniah, C., Ravikumar, A. \& Thangavel, K. 2018. Genetic improvement of fungal pathogens. Advances in Plants and Agriculture Research 8(1): 4-9.

Patil, N.S., Patil, S.M., Govindwar, S.P. \& Jadhav, J.P. 2015. Molecular characterization of intergeneric hybrid between Aspergillus oryzae and Trichoderma harzianum by protoplast fusion. Journal of Applied Microbiology 118(2): 390-398.

Peng, G. \& Xia, Y. 2015. Integration of an insecticidal scorpion toxin (BjaIT) gene into Metarhizium acridum enhances fungal virulence towards Locusta migratoria manilensis. Pest Management Science 71(1): 58-64.

Reddy, S.G.E. \& Sahotra, S. 2018. Multiplication of entomopathogenic fungus (Lecanicillium lecanii) on apple pomace and its toxicity against aphid (Aphis craccivora). Toxin Reviews 39(8): 1-6.

Ruiu, L. 2018. Microbial biopesticides in agroecosystems. Agronomy 8(11): 235.

Singh, H.B., Keswani, C., Ray, S., Yadav, S.K., Singh, S.P., Singh, S. \& Sarma, B.K. 2015. Beauveria bassiana: Biocontrol beyond lepidopteran pests. In Biocontrol of Lepidopteran Pests. New York: Springer. pp. 219-235.

Solter, L.F., Hajek, A.E. \& Lacey, L.A. 2017. Exploration for Entomopathogens. In Microbial Control of Insect and Mite Pests. New York: Elsevier Inc. pp. 13-23.

Strom, N.B. \& Bushley, K.E. 2016. Two genomes are better than one: History, genetics, and biotechnological applications of fungal heterokaryons. Fungal Biology and Biotechnology 3: 4 .

Vega, F.E., Goettel, M.S., Blackwell, M.S.A., Chandler, D., Jackson, M.A., Keller, S., Koike, M., Maniania, N.K., Monzon, A., Ownley, B.H., Pell, J.K., Rangel, D.E.N. \& Roy, H.E. 2009. Fungal entomopathogens: New insights on their ecology. Fungal Ecology 2(4): 149-159.

Wang, D., Deng, J., Pei, Y., Li, T., Jin, Z., Liang, L., Wang, W., Li, L. \& Dong, X. 2017. Identification and virulence characterization of entomopathogenic fungus Lecanicillium attenuatum against the pea aphid Acyrthosiphon pisum (Hemiptera: Aphididae). Applied Entomology and Zoology 52(3): 511-518.
White, T.J., Bruns, T., Lee, S. \& Taylor, J.W. 1990. Amplification and direct sequencing of fungal ribosomal RNA genes for phylogenetics. In PCR Protocols: A Guide to Methods and Applications, edited by Innis, M.A., Gelfand, D.H., Sninsky, J.J. \& White, T.J. Oxford: Academic Press. pp. 315-322.

Wraight, S.P., Lopes, R.B. \& Faria, M. 2017. Microbial control of mite and insect pests of greenhouse crops. In Microbial Control of Insect and Mite Pests. Oxford: Academic Press. pp. 237-252.

Wu, J.D. \& Chou, J.C. 2019. Optimization of protoplast preparation and regeneration of a medicinal fungus Antrodia cinnamomea. Mycobiology 47(4): 483-493.

Xie, M., Zhang, Y.J., Zhai, X.M., Zhao, J.J., Peng, D.L. \& Wu, G. 2015. Expression of a scorpion toxin gene BmKit enhances the virulence of Lecanicillium lecanii against aphids. Journal of Pest Science 88(3): 637-644.

Zare, R., Gams, W. \& Culham, A. 2000. A revision of Verticillium sect. Prostrata. I. Phylogenetic studies using ITS sequences. Nova Hedwigia 71: 465-480.

Zhang, Y.J., Xie, M., Zhang, X.L., Peng, D.L., Yu, W.B., Li, Q., Li, Q., Zhao, J.J. \& Zhang, Z.R. 2016. Establishment of polyethylene-glycol-mediated protoplast transformation for Lecanicillium lecanii and development of virulenceenhanced strains against Aphis gossypii. Pest Management Science 72(10): 1951-1958.

Liang Liu

Heilongjiang Academy of Agricultural Sciences

Postdoctoral Programme

Harbin, Heilongjiang, 150086

China

Chunlai Liu, FanYang, Shuang Wang, Xifeng Jiang \& Xinmin Li* Institute of Plant Protection (IPP)

Heilongjiang Academy of Agricultural Sciences

Scientific Observing and Experimental Station

of Crop Pest in Harbin

Ministry of Agriculture

Harbin, Heilongjiang, 150086

China

Lili Yan

School of Chemistry and Chemical Engineering

Shanghai University of Engineering Science

Shanghai, 201620

China

*Corresponding author; email: shengfangshi408@126.com

Received: 6 March 2019

Accepted: 13 October 2020 